Research Article

\title{
The Association between Menstrual Disorder and Work Disturbance among Employees
}

\author{
Hubungan Gangguan Menstruasi dan Gangguan Kerja pada Karyawati \\ Laila Nuranna, Iftikar Abdullah, I. Putu G. Kayika, Gita Pratama
}

\author{
Department of Obstetrics and Gynecology \\ Faculty of Medicine Universitas Indonesia/ \\ Dr. Cipto Mangkusumo Hospital \\ Jakarta
}

\begin{abstract}
Objective: To investigate the association between menstrual disorders including each menstrual cycle disorder, duration and volume of menstrual bleeding disorder, menstrual interval disorder, and another disorder that related to menstruation against disruption of work among employees.

Methods: This study used a cross sectional design. Sample randomization with winpepi ${ }^{\circledR}$ software for Windows $7^{\circledR}$. Data analysis using SPSS $24{ }^{\circledR}$ software for Windows $7{ }^{\circledR}$.

Results: A total of 150 subjects were recruited in this study. The prevalence of menstrual disorder was $87 \%$, menstrual cycle disorder 3\%. Menstrual volume disorder 31\%, 15\% menstrual abnormalities, $83 \%$ menstrual pain disorder and premenstrual syndrome $71 \%$. Prevalence of work disturbance was $49 \%$ for mild disturbance, $47 \%$ for moderate disturbance and severe work disturbance by $4 \%$. There was a relationship between menstrual volume disorder, hypermenorrhoea, and menstrual / dysmenorrhoea pain to occupational disruption among the employee at RSCM ( $p<0.001)$. The submission of the proposed leaves due to menstrual disorder in the proposed permit for 1 day by $73 \%$.
\end{abstract}

Conclusion: The prevalence of severe work disturbance due to menstruation is not high but can lead to disruption in running jobs and activities. However, it is important to be a concern so that the employees get good management and care.

[Indones J Obstet Gynecol 2018; 6-1: 10-17]

Keywords: employee, menstrual leave, menstrual disorder, prevalence, work disturbance

\begin{abstract}
Abstrak
Tujuan: Untuk mengetahui hubungan antara gangguan menstruasi termasuk setiap gangguan siklus menstruasi, durasi dan volume gangguan perdarahan menstruasi, gangguan interval menstruasi, dan kelainan lain yang berhubungan dengan menstruasi terhadap terganggunya kerja pada karyawan.
\end{abstract}

Metode: Penelitian ini menggunakan desain potong lintang dengan jumlah sampel sebanyak 150 responden. Pengacakan sampel dengan perangkat lunak winpepi® untuk Windows $7 \otimes$. Analisis data menggunakan software SPSS $24{ }^{\circ}$ untuk Wndows $70^{\circ}$,

Hasil: Prevalensi gangguan menstruasi adalah 87\%, gangguan siklus haid 3\%. Gangguan volume menstruasi 31\%, kelainan menstruasi $15 \%, 83 \%$ gangguan nyeri haid dan sindrom pramenstruasi $71 \%$. Prevalensi 49\% gangguan kerja ringan, gangguan kerja sedang 47\% dan gangguan kerja berat sebesar 4\%. Adanya hubungan antara gangguan volume menstruasi, hipermenorea, dan nyeri haid / dismenore terhadap gangguan kerja di antara karyawan di RSCM ( $p<0,001)$. Pengajuan hari cuti yang diusulkan karena gangguan menstruasi terbanyak adalah 1 hari yaitu sebesar $73 \%$

Kesimpulan: Prevalensi gangguan berat pekerjaan akibat haid tidaklah tinggi namun bisa mengakibatkan terganggunya pekerjaan dan aktivitas yang berjalan, namun, penting untuk menjadi perhatian agar karyawan mendapatkan manajemen dan perawatan yang baik. [Maj Obstet Ginekol Indones 2018; 6-1: 10-17]

Kata kunci: cuti haid, gangguan haid, gangguan kerja, karyawan, prevalensi

\section{INTRODUCTION}

Menstruation is a God-given nature to women. Menstruation is like a close friend who is present to accompany a woman every month. However, sometimes menstruation can be unpleasant and may lead to problems named as menstrual disorders. According to the World Health Organization (WHO), approximately about 18 million women aged 30-55 years experienced menstrual disorders in the form of excessive menstrual blood. ${ }^{1}$ In the work environment, the majority hospital workers are dominated by women workers, particularly those who work as nurses. $^{2}$ In the female worker's group, menstrual disorders, including premenstrual syndrome, menstrual pain disorder (dysmenorrhoea), long disturbance and amount of bleeding, and menstrual cycle disorders, often occur. ${ }^{3}$

Menstrual disorders among female workers cannot be disregarded. Dysmenorrhoea, long disturbances, as well as long and excessive menstrual periods (hypermenorrhoea), may affect 
women's quality of life and economically lead to reduced income due to lost working time and work productivity of the women workers for 2-3 days in each month. ${ }^{1,4}$ In fact, because of their business or perhaps due to the lack of awareness and limited understanding of menstrual disorders, they sometimes have less chance to find the cause of the menstrual disorder. If the menstrual disorder an excessive amount of bleeding caused by involves endometrial hyperplasia, it usually occurs at the age of menopause but also by $25 \%$ of cases can occur at perimenopausal age and by $5 \%$ at age less than 40 years. $^{5,6}$ If the type of hyperplasia is included Atypical groups will increase the risk of endometrial cancer by $8 \%$ in type Simple Atypical Hyperplasia (SAH) and 29\% in Complex Atypical Hyperplasia $(\mathrm{CAH})$ if the endometrial hyperplasia is not treated promptly. ${ }^{7}$ Complaints of menstrual disorders can also occur in cervical cancer in women aged $25-65$ years. $^{8}$

Studies regarding menstrual disorders among adolescents, women workers, and nurses abroad have been done. ${ }^{2,3,9}$ Among them through study results Nohara, et al mentions the prevalence of menstrual pain disorder (dysmenorrhea) and menstrual cycle disorders among office workers in Japan is quite high Namely by $76.5 \%$ and $17.1 \%$. Meanwhile, according to Smith, et al. mentioned that the prevalence rate of menstrual cycle disturbances, other menstrual disorders in this case in the form of menstrual pain (dysmenorrhea), and premenstrual syndrome, among nurses in Japan, were $24.9 \%, 44.6 \%$, and $42.2 \%$. Nohara et al. found that there was a possibility of linkage to the increase of menstrual cycle disorders and menstrual pain disorder in the employee who experiencing stress. ${ }^{2,3}$ Then how about the similar study in Indonesia, it turns out the study on new menstrual disorders reside in student or the adolescent environment. ${ }^{10}$ However, the study on menstrual disorders among employee working in hospital environments in Indonesia is still very limited.

On the other hand, the Government of Indonesia has actually shown its care through the Law of the Republic of Indonesia number 13, 2013 on Employment in article 81 on the permissibility of taking menstrual leave due to menstrual pain experienced by a woman worker for 2 days on the first day and second at the time of menstruation. ${ }^{11,12}$ The law was established with the aim to protect women workers in Indonesia. Both formal and informal sectors that experience problems of menstrual disorders especially pain during menstruation. The purpose of the policy is actually expected that women workers who experience menstrual disorders can use this time to examine himself to the expert doctor about the disorder are to find the cause and treat menstrual disorders are. In fact, similar policies have not yet existed in the working environment of Government Hospital. The absence of such policy could be due to the absence of such menstrual leave policy, due to the absence of any obvious problems regarding menstrual disorders, so that the policy is difficult to consider. So to answer the above, this study is done with the aim to know the characteristics of menstruation and prevalence of menstrual disorder that happened to the worker who works in a hospital environment, and this study also conducted as one of the means to increase awareness and knowledge from the women about their menstrual disorders. The results of this study can also be used as a basis to determine whether or not the existence of a new policy regarding the giving of leave time on the employee who experienced menstrual disorders in terms of how big the problem occurred.

\section{METHODS}

This was a cross-sectional study. The survey was conducted at Dr. Cipto Mangunkusumo National General Hospital (RSUPNCM) Jakarta. Study and sampling using questionnaires and diary forms of menstrual disorders began in January 2017 until April 2017. Inclusion criteria were RSCM employees who were willing to follow the study, employee aged 20-50 years. The lowest age is the average age of women employed in RSCM, while the upper age is used based on the 2004 PERMI survey of the average age of menopause in Indonesia. ${ }^{13}$ The exclusion criteria in this study were those who were pregnant and not experiencing pregnancy within 3 months. Prior to informed consent, and respondents have experienced menopause. Based on the calculation of the number of respondents, then the respondent's minimum in this study the researchers chose the results of large sample calculations based on the proportion of respondents in the largest case of menstrual pain (dysmenorrhoea) as 138 respondents. Large respondents are 
considered capable of management as respondents study in this study. Respondents in this study were part of affordable population selected after selection through inclusion and exclusion criteria, then respondents were randomized using simple random sampling method for the employee who worked at RSCM who was in the workplace when survey by the researchers who then included in the study until the number of respondents desired is met. From employment data as of $31^{\text {st }}$ October 2016, there is a total of 3700 employees of the study process conducted in January 2017 to April 2017. The results of the questionnaires were collected and checked by the respondents within 30 minutes of the questionnaire. All Collected data is recorded and analyzed. A questionnaire was validated by cronbach alpha method using the software program SPSS $24^{\circledR}$ for Windows $7^{\circledR}$ program. The questionnaire has been validated to 20 employees using winpepi ${ }^{\circledR}$ software for Windows $7^{\circledR}$ and obtained by alpha cronbach value of 0.8 with good internal consistency criteria.

All statistical analyses were performed using SPSS 24 for Windows. Results were displayed in the form of frequency, percentage (proportion), the average (mean), median, range values (range). Normality test data distribution to the numerical data that is Kolmogorov-Smirnov and ShapiroWilk test the hypothesis is done by using analytic comparative categorical unpaired such as Chisquare and alternatives that Kolmogorov-Smirnov when not qualify Chi-square test and test analytic comparative numerically paired unpaired test when data distribution was normal and alternatives such as the Mann-Whitney test if data distribution is not normal that is used to verify a possible correlation between the variables. All hypothesis test analysis results are shown with significance level $\mathrm{p}<0.05$.

\section{RESULTS}

The number of study subjects that can be collected as many as 150 people, obtained from the employee working at RSCM in Building A, Kirana and Kiara RSCM in the period November of 2016 until April 2017.
Table 1. Subject Characteristics

\begin{tabular}{|c|c|}
\hline Variable & $\begin{array}{c}\text { Number of subject } \\
(\%), N=150\end{array}$ \\
\hline \multicolumn{2}{|l|}{ Age group (years) } \\
\hline$<25$ & $33(22)$ \\
\hline $25-29$ & $40(27)$ \\
\hline $30-34$ & $19(13)$ \\
\hline $35-39$ & $31(21)$ \\
\hline $40-44$ & $15(10)$ \\
\hline $45-49$ & $10(7)$ \\
\hline $50-54$ & $2(1)$ \\
\hline \multicolumn{2}{|l|}{ BMI $\left(\mathrm{kg} / \mathrm{m}^{2}\right)$} \\
\hline$<18.5$ & $8(5)$ \\
\hline $18.5-25.0$ & $98(65)$ \\
\hline$\geq 25.0$ & $31(21)$ \\
\hline$>30$ & $13(9)$ \\
\hline \multicolumn{2}{|l|}{ Education } \\
\hline Senior High School & 7 (5) \\
\hline D3 & $108(72)$ \\
\hline D4 & $4(2)$ \\
\hline S1 & $31(21)$ \\
\hline \multicolumn{2}{|l|}{ Marital Status } \\
\hline Married & $101(67)$ \\
\hline Not yet married & $49(33)$ \\
\hline \multicolumn{2}{|c|}{ Number of Pregnancy } \\
\hline 0 & $63(42)$ \\
\hline$\geq 1$ & $87(58)$ \\
\hline \multicolumn{2}{|l|}{ Number of Labor } \\
\hline 0 & $64(42.7)$ \\
\hline$\geq 1$ & $86(57.3)$ \\
\hline \multicolumn{2}{|c|}{ Number of Misscariage } \\
\hline Never & $128(85)$ \\
\hline$\geq 1$ times & $22(15)$ \\
\hline \multicolumn{2}{|l|}{ Work status } \\
\hline Permanent worker & $127(85)$ \\
\hline Unfixed worker & $23(15)$ \\
\hline \multicolumn{2}{|l|}{ Shift work } \\
\hline Morning Shift & 145 (96.7) \\
\hline Afternoon Shift & $116(77.3)$ \\
\hline Night Shift & 113 (75.) \\
\hline One-Shift & $31(21)$ \\
\hline Two-Shift & $5(3)$ \\
\hline All shift & $114(76)$ \\
\hline
\end{tabular}




\begin{tabular}{|c|c|}
\hline \multicolumn{2}{|l|}{ Work hours } \\
\hline$<7$ hours/day & $3(2)$ \\
\hline 8-10 hours/day & $139(93)$ \\
\hline$>10$ hours/day & $8(5)$ \\
\hline \multicolumn{2}{|l|}{ Position on work } \\
\hline Sitting & $17(11)$ \\
\hline Standing/walking & $18(12)$ \\
\hline Both & $115(77)$ \\
\hline \multicolumn{2}{|l|}{ Sleep duration } \\
\hline$<6$ hours & $59(39)$ \\
\hline$>6$ hours & $91(61)$ \\
\hline \multicolumn{2}{|l|}{ Smoking habits } \\
\hline Active smoker & $0(0)$ \\
\hline Pasive smoker & $0(0)$ \\
\hline Non smoker & $150(100)$ \\
\hline \multicolumn{2}{|l|}{ Exercise } \\
\hline Yes & $1(1)$ \\
\hline Not & 149 (99) \\
\hline \multicolumn{2}{|l|}{ Age of menarche } \\
\hline 9 & $0(0)$ \\
\hline 10 & $2(1)$ \\
\hline 11 & $10(7)$ \\
\hline 12 & $51(34)$ \\
\hline$>12$ & $87(58)$ \\
\hline \multicolumn{2}{|l|}{ Menstrual duration } \\
\hline$<3$ days & $0(0)$ \\
\hline 3-7 days & $125(83)$ \\
\hline$>7$ days & $25(17)$ \\
\hline \multicolumn{2}{|l|}{ Contraception } \\
\hline Natural contraception & $2(1)$ \\
\hline Condom & $7(5)$ \\
\hline Amenorea Lactation methods & $0(0)$ \\
\hline $\mathrm{COC}$ & $4(3)$ \\
\hline Minipil & $0(0)$ \\
\hline 1 month injection contraception & $0(0)$ \\
\hline 3 month injection contraception & $4(3)$ \\
\hline Implant & $0(0)$ \\
\hline IUD & 27 (18) \\
\hline Tubectomy & $2(1)$ \\
\hline Not used & $104(69)$ \\
\hline
\end{tabular}

From the result above, the highest employee age range is aged $25-29$ years by 40 employee (27\%). The mean value of the worker's age is 31.8 years with a standard deviation value of 7.9 years. The age of the youngest employee respondents is 21 years old with the age of the oldest employee respondents is 52 years old. From this result it can be seen that the average of worker's age is slightly younger than the result of the study on the previous employee in Japan. ${ }^{2}$

About $65 \%$ of employees at RSCM have average BMI of Normal Weight (Normoweight) category

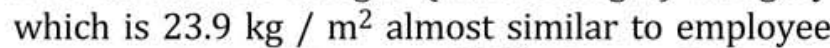
in Japan, USA and Norway. 2,4,14 The employees at RSCM are dominated by D3 level of education as much as $108(72 \%)$. The second is S1 (31\%), high school education $(7 \%)$ and $4(3 \%)$ of D4 education.

From the above study shows that the majority of workers as many as 101 people (67\%) employees had been married and 49 people (33\%) unmarried employee. In contrast to previous study results that the majority was dominated by unmarried workers. ${ }^{2}$

Majority of the workers were married and have had 87 pregnant women (58\%). Employees who have never had a pregnancy are $63(42 \%)$ but only $14(9 \%)$ are actually married but have never been pregnant and $49(\%)$ are unmarried. And have never been pregnant. With a mean value of 1.82 pregnancies with standard deviation of 1.3 pregnancies. With a median of 2 pregnancies.

A total of 86 workers (57.3\%) who were married experienced pregnancy, and later there were 14 people $(9.3 \%)$ who were married but had never been pregnant or had labor and had experienced labor and there were only $1(0.7 \%)$ employed married then pregnant but had never experienced labor because of miscarriage. As many as $57.3 \%$ of workers in this study had experienced labor. The average number of deliveries was 1.61 births with standard deviation of 1.04 births. With a median value of 2 deliveries. Compared to previous study, the number of marriages among RSCM employees was quite high, similar to that of Gordley et al. study, among 56\% of female workers in the United States, 56.3\% had been married and $58.3 \%$ have children. Then for pregnancy and delivery rates in this study was higher than in Japan according to Nohara et al. were as much as $40.5 \%$ had experienced pregnancy and as much as $38.4 \%$ had experienced labor. Thus the nulliparous rate in this study was less than the results of study on the previous employee in Japan that was equal to $60.4 \%$ of 
employees have not had children..$^{3,4}$

From the table above shows that there are 22 people worker (15\%) have experienced miscarriage. As many as 128 employees (85\%) had never experienced a miscarriage. With a mean value of 1.03 miscarriage and a standard deviation value of 0.86 miscarriage. Then obtained the median value of 1 miscarriage. Employment status is dominated by permanent workers, ie 127 workers (85\%). And workers are not fixed as many as 23 employee (15\%).

From the division of working time there are 93 employees (38\%) who work on 3 shifts division of working time in the morning, afternoon and night shift.

Based on working hours, 139 workers (93\%) worked for 8-10 hours per day. A total of 8 employees (5\%) work more than 10 hours per day and as many as 3 employees (3\%) work less than 7 hours per day. With the average value of working for 8.3 hours with a standard deviation value of 1 hour. With a median value of 8 hours. The length of working hours is almost similar to the length of working hours employed based on previous study in Japan with a mean value of 8.9 hours and standard deviation 1 hour. $^{2}$
Based on the position at work obtained results that as many as 11 employees (45\%) work in 3 positions of sitting, standing and walking. Then based on long hours of sleep there are 91 people $(61 \%)$ with long hours of sleep more than 6 hours per day. While on the worker with long hours of sleep less equal to 6 hours per day was as many as 59 people (39\%).

From the table shows there are 150 respondents $(100 \%)$ had never smoked. And there were 149 employees (99\%) who did not exercise regularly and 1 person (1\%) was used to regular exercise.

Based on the age of menarche, it was found that most of the employees had menarche age more than 12 years (58\%). Age 12 years of 51 (34\%). Age 11 years as many as 10 people employee (7\%). Age 10 years as many as 2 employee (1\%). With a mean value of 13 years with standard deviation of 1.3 years, and median value at age 13 years.

Based on the duration of menstruation there are 125 people (83\%) with menstrual period 3-7 days. Then as many as 25 employee (17\%) with menstrual period of more than 7 days. The mean value was 6.6 days and the standard deviation value was 1.65 days. With median duration of menstruation was 7 days.

Table 2. Correlation between Menstrual Disorder and Work Disturbance

\begin{tabular}{|c|c|c|c|c|c|c|c|c|c|c|}
\hline & & \multicolumn{6}{|c|}{ Work disturbance } & \multirow{3}{*}{ *X2 } & \multirow{3}{*}{${ }^{*} \mathbf{p}$} & \multirow{3}{*}{$\begin{array}{l}\text { **Asymp. Sig } \\
\text { (2-tailed) }\end{array}$} \\
\hline & & \multicolumn{2}{|c|}{ mild } & \multicolumn{2}{|c|}{ moderate } & \multicolumn{2}{|c|}{ severe } & & & \\
\hline & & $\mathbf{n}$ & $\%$ & $\mathbf{n}$ & $\%$ & $\mathbf{n}$ & $\%$ & & & \\
\hline \multirow{2}{*}{ Menstrual disorder } & Not disturbed & 17 & 11.3 & 2 & 1.3 & 0 & 0 & \multirow{2}{*}{14.065} & \multirow{2}{*}{0.001} & \multirow[t]{2}{*}{-} \\
\hline & Disturbed & 57 & 38 & 68 & 45.3 & 6 & 4 & & & \\
\hline \multirow{2}{*}{$\begin{array}{l}\text { Menstrual cycle } \\
\text { disorder }\end{array}$} & Not disturbed & 71 & 95.9 & 69 & 98.6 & 6 & 100 & \multirow{2}{*}{1.127} & \multirow{2}{*}{0.569} & \multirow{2}{*}{0.949} \\
\hline & Disturbed & 3 & 4.1 & 1 & 1.4 & 0 & 0 & & & \\
\hline \multirow{2}{*}{$\begin{array}{l}\text { Menstrual volume } \\
\text { disorder }\end{array}$} & Not disturbed & 63 & 42 & 39 & 26 & 2 & 1.3 & \multirow{2}{*}{18.454} & \multirow{2}{*}{0.000} & \multirow{2}{*}{0.000} \\
\hline & Disturbed & 11 & 7.3 & 31 & 20.7 & 4 & 2.7 & & & \\
\hline \multirow{2}{*}{$\begin{array}{l}\text { Menstrual periode } \\
\text { disorder }\end{array}$} & Not disturbed & 66 & 44 & 58 & 38.7 & 4 & 2.7 & \multirow{2}{*}{2.892} & \multirow{2}{*}{0.235} & \multirow{2}{*}{ - } \\
\hline & Disturbed & 8 & 5.3 & 12 & 8 & 2 & 1.3 & & & \\
\hline \multirow{2}{*}{ Hypermenorea } & Not disturbed & 59 & 39.3 & 36 & 24 & 2 & 1.3 & \multirow{2}{*}{15.295} & \multirow{2}{*}{0.000} & \multirow{2}{*}{0.001} \\
\hline & Disturbed & 15 & 10 & 34 & 22.7 & 4 & 2.7 & & & \\
\hline \multirow{2}{*}{ Dismenorea } & Not disturbed & 23 & 15.3 & 3 & 2 & 0 & 0 & \multirow{2}{*}{19.5} & \multirow{2}{*}{0.000} & \multirow{2}{*}{0.000} \\
\hline & Disturbed & 51 & 34 & 67 & 44.7 & 6 & 4 & & & \\
\hline \multirow{3}{*}{$\begin{array}{l}\text { Premenstrual } \\
\text { syndrome }\end{array}$} & Not disturbed & 22 & 14.7 & 19 & 12.7 & 1 & 0.7 & \multirow{2}{*}{0.518} & \multirow{2}{*}{0.772} & \multirow{2}{*}{1.000} \\
\hline & Disturbed & 52 & 34.7 & 51 & 34 & 5 & 3.3 & & & \\
\hline & & 74 & 100 & 70 & 100 & 6 & 100 & & & \\
\hline
\end{tabular}


Table 3. Correlation between Level of Pain with VAS Score, PBAC Score and Work Disturbance

\begin{tabular}{llcccc}
\hline VAS Score & & & & & \\
\hline & & $\mathbf{n}$ & $\begin{array}{c}\text { Median } \\
\text { (Minimum-Maximum) }\end{array}$ & Mean \pm SD & p \\
\hline Work disturbance & Mild & 74 & $2(0-6)$ & $1.77 \pm 1.46$ & $3.74 \pm 1.66$ \\
& Moderate & 70 & $4(0-8)$ & $0.168 \pm 0.84$ & \\
& Severe & 6 & $8(6-8)$ & & $<01$ \\
\hline PBAC score & & & & $74.9 \pm 36.0$ & $113.9 \pm 86.5$ \\
\hline Work disturbance & Mild & 74 & $96(10-456)$ & $130 \pm 35.8$ & \\
& Moderate & 70 & $132(81-170)$ & \\
\hline \hline
\end{tabular}

VAS score vs work disturbance : Kruskall-wallis test. Post hoc Mann-Whitney test: severe vs moderate $p<0.001$;

Severe vs mild $p<0.001$; moderate vs mild $p<0.001$

PBAC score vs work disturbance: Kruskall-wallis test. Post hoc Mann-Whitney test :severe vs moderate $p<0.135$;

severe vs mild $p=0.003$; moderate vs mild $p=0.001$

Of the 101 married workers, $46(45.5 \%)$ married workers used contraceptive methods while $55(54.5 \%)$ did not use any method of contraception. The highest type of contraception methods was IUD with $27(26.7 \%)$ subjects.

Based on the distribution of respondents who experienced menstrual disorders were 131 employees (87.3\%) and 19 employees (12.6\%) did not experience menstrual disorders.

Based on the proportion of the distribution of respondents by type of menstrual disorders that most are in other disorders associated with menstruation as many as 130 people $(87 \%)$, followed by disruption volume of menstrual many as 46 people $(31 \%)$, disruption of menstrual periode as many as 22 people (14.6\%), and disruption of other menstrual bleeding outside the menstrual cycle 4 people (3\%). This result is in accordance with previous studies. ${ }^{2-4}$

\section{DISCUSSION}

In this study, the most menstrual cycle disorder type was the case of polymenorrhea as much as 3 subjects $(2 \%)$ and oligomenorrhea as much $(1 \%)$. In other studies, according to Smith et al. mention that menstrual cycle disorder is as much as $24.9 \%$, then according to Nohara et al. is $17.1 \%$. According to Gordley et al. said menstrual pain among military personnel in the United States is $12 \%$. Meanwhile, according to Moen et al. for menstrual cycle disorders at an employee in Norway amounted to $19 \%$ with polimenorea $17 \%$ and oligomenorrhea of $2 \% .^{2-4,14}$
Then the type of highest menstrual periode and the menstrual volume disorders is hypermenorea (Menorragia / Heavy Menstrual Bleeding / HMB) as many as 53 people (35\%). According Gordley et al. said for a menstrual periode and menstrual volume disorders amounted to $17.9 \%$, while according to Moen et al. study just mentioned about the menstrual periode disorders that is equal to $20 \%$ and $19 \%$ for Hipomenorea. ${ }^{4,14}$

While in the assessment of bleeding disorders outside the menstrual cycle results obtained no employee bleeding disorders outside the menstrual cycle (metroragia / intermenstrual bleeding). Lack of study exists on the results of menstrual cycle disorders and bleeding disorders outside the menstrual cycle which comparatively few because making questionnaire answers by using diaries menstruation is only done on the observation of menstruation within 1 month prior to filling the questionnaire which should be monitoring menstrual cycle disorders should be at least in the next 3 months after filling the questionnaire, but also due to the limited time of study from the researcher while the respondents of the study mostly only able to remember and record of when the menstruation of each respondent is not good, causing the least number of menstrual cycle disorders.

In this study, we found that, based on other disorders associated with menstruation, it was found that were dysmenorrhea $124(83 \%)$ and premenstrual syndrome were $107(71 \%)$. This is in accordance with previous study, Nohara et al. in Japan, the prevalence rate of menstrual pain 
disorder (dysmenorrhea) among office workers in Japan is quite high at $76.5 \%$. Meanwhile, Smith et al. found that menstrual pain (dysmenorrhoea) among nurses in Japan was $90.1 \%$ which was divided into the pain is occasionally felt by $45.5 \%$ and pain was always felt by $44.6 \%$, while for premenstrual syndrome $88.7 \%$ divided into occasionally premenstrual syndrome $42.2 \%$ and always feel premenstrual syndrome equal to $46.5 \%$. While Gordley et al. said menstrual pain among military personnel in the United States amounted to $31.2 \%$, the study found that most complaints in employee complaints is in the form of painful menstruation or dysmenorrhea and premenstrual syndrome. . $^{2-4}$

Based on the degree of menstrual pain using VAS score, it was found that most complaints were mild pain complaints of $65 \%$, followed by moderate pain complaints of $29 \%$, and then $6 \%$ of employee complained of severe pain.

Based on the location of pain relief most painful menstruation is felt to spread to the lower abdomen as much as $56 \%$, pain $22 \%$ waist, stomach pain that spread to the thigh as much as $5 \%$ and pain relief to other places such as thighs and anus as much as $3 \%$, while as many as $14 \%$ the employee said there were no pain complaints.

Based on the types of complaints related to menstruation, it is found that most mental complaints are in the form of irritability and irritability by $31 \%$, followed by easy complaints of weakness, fatigue and lethargy and tiredness as much as $21 \%$, mood changes that arrived (feelings of sudden sadness) as much as $18 \%$, appetite increased by $8.7 \%$, anxiety and tension feeling as much as $3.8 \%$, feelings of sadness and no hope as much as $3.5 \%$, easy to fall asleep and difficulty awakened or lack of sleeplessness as much as $2.1 \%$, while as many as $8.7 \%$ employee admitted no complaints to the mental. While in the study of Smith et al. there are few differences where it is mentioned that most mental complaints are in the form of weakness, fatigue and lethargy and fatigue of $23.4 \%$, excessive hunger by $11.5 \%$, difficulty sleeping by $3 \%$, anxious excess of $2.9 \%$, decreased appetite $2.4 \%$.

Based on the physical complaints obtained results that most complaints are in the form of pain complaints in the breast as much as $32 \%$, followed by breast swelling of $19 \%$, abdominal bloating $16 \%, 14 \%$ headache, swelling in the arm or leg as much as $1 \%$, pain in the buttocks $1 \%$, body poppy $0.5 \%$ and acne $0.5 \%$. According to Smith's et al. study there are 4 most physical complaints from the Japanese workers, namely $49.2 \%$ breast pain especially felt before the menstrual period. Then $47.3 \%$ of stomach pain was felt before menstruation and increased during menstruation lasting that is equal to $76.2 \%, 42.6 \%$ of waist pain felt higher when menstruation equal to $64 \%$, and headache felt at $24.3 \%$ and decreased during menstruation took place in as many as $22.9 \%$ of employees in Japan. ${ }^{2}$

Later in this study obtained the results of the most impact of menstrual disorders on the work was a mild impact and does not interfere with activity and work by $49 \%$ and not much different from the impact of interference while there are $47 \%$ feel the impact of menstrual disorders, where the employees can still continued work despite being disturbed. Severe disturbance is felt in $4 \%$ of employees.

From this study it is known that the relationship between menstrual volume disorder, hypermenorrhea, and menstrual pain / dysmenorrhoea have a relationship with work disruption at the employee at RSCM with $(\mathrm{p}<0.001)$. While the menstrual cycle and the menstrual periode disorder and premenstrual syndrome have no relation to work disruption at employee at RSCM (Table 2).

VAS score with moderate and severe pain has correlated with work disturbance $(p<0.001)$ and PBAC score with moderate and severe has correlated with work disturbance $(\mathrm{p}<0.005)$ (Table 3).

Based on the permit break due to work disruption where there was $16 \%$ using a permit to rest due to menstrual disorders. The length of permit taken is $20.7 \%$ taking 1 day leave and as much as $0.7 \%$ taking the menstrual leave for 2 days. But mostly $78.7 \%$ of the employee did not take time off.

Most of the workers did not know about menstruation leave policy where only $15 \%$ of employee who know of menstrual leave policy, most policies are made in private hospitals, and as many as $85 \%$ of workers mention not knowing the existence of menstruation leave.

The proposed leave of absence from menstrual abnormalities in the proposed permit for 1 day $(73 \%)$, then as many as $18 \%$ apply for leave for 
2 days, while as many as $15 \%$ said not require menstruation leave.

\section{CONCLUSION}

The prevalence of severe labor disruption due to menstruation is not high but can lead to disruption in running jobs and activities. However, it is important to be a concern so that the employees get right management and care. Menstrual volume disorders, hypermenorrhoea, and menstrual pain/ dysmenorrhoea have a significant relationship with work disturbance at the RSCM employee. While the menstrual cycle disturbances, menstrual periode disturbances and premenstrual syndrome have no relation to work disturbance at employee at RSCM.

\section{REFERENCES}

1. Karout N, Hawai SM, Altuwaijri S. Prevalence and pattern of menstrual disorders among Lebanese nursing student. East Mediterr Health J. 2012; 18(4): 346-452.

2. Smith DR, Mihashi M, Adachi Y, Shouyama Y, Mouri F, Ishibashi $\mathrm{N}$, et al. Menstrual disorders and their influence on low back pain among Japanese nurses. Ind Health. 2009; 47(3): 301-12.

3. Nohara M, Momoeda M, Kubota T, Nakabayashi M. Menstrual cycle and menstrual pain problems and related risk factors among Japanese female workers. Ind Health. 2011; 49(2): 228-34.

4. Gordley LB, Lemasters G, Simpson SR, Yiin JH. Menstrual disorders and occupational, stress, and racial factors among military personnel. J Occup Environ Med. 2000; 42(9): 87181.
5. Plataniotis G, Castiglione M. Endometrial cancer: ESMO Clinical Practice Guidelines for diagnosis, treatment and follow-up. Ann Oncol. 2010; 21 (Supp 5): 41- 5.

6. The University of Texas MD Anderson Cancer Center. Patient and Cancer Information: Uterine Cancer. 2013 [cited 2013 June 2]. Available from: http://www.mdanderson.org/patient-and-cancer-information/cancer-informati on/cancer-types/uterine-cancer/index.html.

7. Endometrial (Uterine) Cancer 2013 [cited 2013 May 31]. Available from: http://www.cancer.org/cancer/endometrialcancer/detailedguide/endometrial-uterine-cancer-risk-f actors.

8. Cancer Study UK. Cervical cancer incidence statistics. 2013 [cited 2013 June 2]. Available from: http://www.cancer studyuk.org/cancer-info/cancerstats/types/cervix/incide nce/uk-cervical-cancer-incidence-statistics.

9. Fujiwara T, Nakata R. Young Japanese college students with dysmenorrhea have high frequency of irregular menstruation and premenstrual symptoms. Open Med Inform J. 2007; 1: 8-11.

10. Sianipar O, Bunawan NC, Almazini P, Calista N, Wulandari P, Rovenska N, et al. Prevalensi Gangguan Haid dan Faktorfaktor yang berhubungan pada Siswi SMU di Kecamatan Pulogadung Jakarta Timur. Maj Kedok Indones. 2009; 59(7): 308-13.

11. Undang-Undang Republik Indonesia No. 13 Tahun 2003 Tentang Ketenagakerjaan, pasal 81.

12. Rizky MA, Haryanto ND. Perlindungan Hukum Terhadap Tenaga Kerja Perempuan dan Hambatan-Hambatan yang Dihadapi. Fakultas Hukum Universitas Sebelas Maret. 2016

13. UPI WF. Menopause Berseri dengan Drosperinone dan Estradiol[cited 2013 June 19]. Available from: www.forum. upi.edu/index.php?topic $=13107.0$.

14. Moen BE, Baste V, Morken T, Alsaker K, Pallesen S, Bjorvatn B. Menstrual characteristics and night work among nurses. Ind Health [Internet]. 2015; 53(4): 354-60. 